УДК 618.36-008.6-037:616.147.3-007.64

\title{
Деякі аспекти патогенезу венозного тромбоемболізму у вагітних
}

\author{
О.В. Пиптюк, Ю.Б. Моцюк
}

Івано-Франківський начіональний медичний університет, кафедра хірургї̈ стоматологічного факультету, кафедра акушерства та гінекологї ім. І.Д. Ланового, Івано-Франківськ

\section{Реферат}

На сьогодні питання несприятливого впливу екстрагенітальної патології судинного генезу із розвитком системних порушень гемостазу, тромбофілічних станів та зміною гемодинаміки у фетоплацентарному комплексі у вагітних $€$ однією з найбільш актуальних проблем сучасного акушерства.

Метою дослідження було зниження акушерських та перинатальних ускладнень у вагітних із варикозною хворобою нижніх кінцівок.

На основі вивчення медичної документації було проведено ретроспективний аналіз, встановлено, що варикозна хвороба нижніх кінцівок у вагітних проявляється у 32,7\%, із наростанням клінічних проявів до III триместру до $69,1 \%$. Провідними чинниками $\epsilon$ обтяжена спадковість по материнській та батьківський лінії $(\mathrm{OR}=6,9)$, плацентарна дисфункція при попередніх вагітностях $(\mathrm{OR}=6,3)$, ендокринно-обмінні порушення $(\mathrm{OR}=2,5)$, надмірна вага $(\mathrm{OR}=4,8)$, тромботичні стани $(\mathrm{OR}=10,8)$. Обстежено 120 жінок із варикозною хворобою нижніх кінцівок, які були розділені на основну групу, із призначенням еластичної компресії, суміші біофлавоноїдів, донатора оксиду азоту та терапії, спрямованої на корекцію гемостазіологічних показників, та групу порівняння, де моніторинг вагітності проводився згідно з загальноприйнятими стандартами.

Напередодні розродження відбувається активація антикоагулянтної системи та предикторів тромботичних ускладнень, таких як гіперфібриногенемія, зменшення кількості тромбоцитів та порушення їх агрегаційної спроможності, зниження рівня антитромбіну III у 1,4 разу та зростання в 1,7 разу Д-димерів. Із прогресуванням вагітності гормональні показники змінювалися: гіперфункція в $38,3 \%$, дисфункція у $11,7 \%$, дисбаланс естріолу та кортизолу у $50,0 \%$ спостережень.

Використання лікувально-профілактичних заходів дозволило знизити частку передчасних пологів у 2,2 разу; прееклампсії, плацентарної дисфункції і дистресу плода - у 2,0 разу, у затримку розвитку плода - у 1,8 разу, зниження рівня постгіпоксичної енцефалопатії - у 2,0 разу.

Ключові слова: варикозна хвороба нижніх кінцівок, плацентарна дисфункція, функціональний стан фетоплацентарного комплексу, прогнозування, лікування.

Some aspects of the pathogenesis of venous thromboembolism in pregnant women Pyptiuk O.V., Motsiuk Yu.B.

Ivano-Frankivsk National Medical University, Department of Surgery of Denta lFaculty, Department of Obstetrics and Gynecology named after I.D. Lanovy

Abstract

Nowadays, the issue of adverse influence of extragenital pathology of vascular genesis with the development of systemic disorders of hemostasis, thrombophilic conditions, and changes in hemodynamics in the fetoplacental complex in pregnant women is one of the most topical problems of modern obstetrics.

The aim of the study was to reduce obstetric and perinatal complications in pregnant women with varicose veins of the lower extremities.

Based on the study of medical records, a retrospective analysis was performed, it was determined that varicose disease of the lower extremities in pregnant women is manifested in $32.7 \%$, with an increase of clinical manifestations before the third trimester up to $69.1 \%$. Leading factors include maternal and paternal heredity $(\mathrm{OR}=6.9)$, placental dysfunction in previous pregnancies $(\mathrm{OR}=6.3)$, endocrine-metabolic disorders $(\mathrm{OR}=2.5)$, overweight $(\mathrm{OR}=4.8)$, thrombotic conditions $(\mathrm{OR}=10.8)$. There were examined 120 women with varicose lower limb disease who were divided into the main group, with the appointment of elastic compression, a mixture of bioflavonoids, a donor of nitric oxide and therapy aimed at the correction of hemostasiological indices, and a comparison group where pregnancy monitoring was performed according to the generally accepted standards.

On the eve of delivery, the activation of the anticoagulant system and predictors of thrombotic complications, such as hyperfibrinogenemia, decrease of platelet number and impairment oftheir aggregation capacity, decrease of antithrombin III level 1.4-fold and increase 1.7-fold of D-dimers. With the progression of pregnancy, the hormonal parameters changed: hyperfunction in $38.3 \%$, dysfunction in $11.7 \%$, imbalance of estriol and cortisol in $50.0 \%$ of observations.

The use of therapeutic-prophylactic measures allowed us toreduce the proportion of preterm births 2.2-fold; preeclampsia, placental dysfunction and fetal distress -2.0 -fold; fetal growth retardation - 1.8 -fold, decrease of post-hypoxic encephalopathy -2.0 -fold.

Key words: varicose disease of the lower extremities, placental dysfunction, functional state of the fetoplacental complex, prognosis, treatment.

Вступ. Венозні тромбози та емболії (ВТЕ) залишаються однією з провідних причин материнської смертності в розвинених країнах, переважно через тромбоемболію легеневої артерії (ТЕЛА) [1]. За ре- 
зультатами досліджень в Свропейському співтоваристві, венозний тромбоз складає в сукупності близько $12 \%$ смертей населення. Це більше, ніж СНІД, рак грудей і дорожньо-транспортні пригоди разом узяті [2].

У структурі широкого спектру соматичної захворюваності варикозна хвороба нижніх кінцівок (ВХНК) займає одне із провідних місць, виявляється в $60 \%$ жіночого населення України. Характерною ознакою для неї $є$ прогресування саме під час вагітності, розвиток системних порушень гемостазу, тромбофілічних станів та зміною гемодинаміки у фетоплацентарному комплексі (ФПК) [3,4].

Венозний тромбоз, це захворювання з п'ятьма різними типами клінічних проявів: тромбоз глибоких вен (ТГВ, Deep Vein Thrombosis, DVT), тромбоемболія легеневої артерії - ТЕЛА (Pulmonary Embolism, PE), хронічна тромбоемболічна легенева гіпертензія (Chronic ThromboEmbolic Pulmonary Hypertension, СТЕРНР). Четвертий прояв - посттромботичний синдром (ПТС, Post Thrombotic Syndrome, PTS), який викликає важкі й інвалідизуючі трофічні ураження шкіри. Смерть, як наслідок ТЕЛА або СТЕРНР, $\epsilon$ п’ятим проявом [5,6].

Незважаючи на значну кількість наукових джерел та літературних повідомлень, питання патогенезу плацентарної дисфункції та негативних перинатальних наслідків у жінок із варикозною хворобою нижніх кінцівок, тромбофіліями є дискутабельними, суперечливими, тому доцільність наукового розгляду даної патології не викликає сумнівів.

Мета дослідження. Аналіз венозного тромбоемболізму у вагітних.

Матеріали та методи. Нами був проведений ретроспективний аналіз медичних карт за останні 5 років і обстеження 120 вагітних із діагностованою на момент диспансерного обліку ВХНК. Пацієнток розподілено на дві групи: перша група - 60 вагітних iз ВХНК, яким проведено загальноприйняті лікувально-профілактичні заходи під час вагітності згідно 3 Національними настановами та наказами МОЗ України. У другій групі (60 вагітних із ВХНК), була проведена еластична компресія вен нижніх кінцівок, застосування суміші біофлавоноїдів (діосмін та гесперидин) у терміни 12-16, 28-32 та 36-40 тижні вагітності; L-аргінін аспартат - у 12-16, 28-32 тижні вагітності, при високому та вкрай високому ступені ризику тромбоемболічних ускладнень - призначення низькомолекулярного гепарину високими профілактичними дозами 3 моменту верифікації стану із відміною препарату за 24 години до імовірного розродження, продовжуючи його введення через 6-8 годин після пологів та впродовж 6-8 тижнів, інгібітора агрегації тромбоцитів 100 мкг на добу з 12 до 36 тижнів вагітності. Контрольну групу склали 30 вагітних без акушерської і соматичної патології, розроджені через природні пологові шляхи.

Аналіз основних критеріїв системи гемостазу проводили в динаміці отриманої терапії у відповідності зі стандартними методиками із застосуванням реактивів «Технологія-Стандарт» та визначенням таких показників: концентрації тромбоцитів, агрегаційна активність за методом флуктуації світло пропускання, час зсідання крові за Лі-Уайтом; час рекальцифікації плазми; толерантність плазми до гепарину; активований парціальний тромбопластиновий час; протромбіновий індекс; тромботест; розчинні фібрин-мономерні комплекси, концентрація фібриногену за Рутбергом; фібриноген В, активність антитромбіну-III (АТ-III), фібринолітична активність крові, а також рівень Д-димерів.

Функціонально-гормональний стан ФПК оцінювали за показниками рівня плацентарних гормонів у сироватці крові: плацентарного протеїну, асоційованого з вагітністю, $\beta$-субодиниці хоріонічного гонадотропіну людини ( $\beta$-ХГЛ), $\alpha$-фетопротеїну та естріолу (E3), плацентарного лактогену, прогестерону, кортизолу та за результатами ехографічного, доплерометричного дослідження у 12-16; 24-28 та 34-38 тижні вагітності та кардіотокографічного дослідження - у 34-38 тижні.

Морфологічні дослідження плацентарної тканини проводили на базі кафедри патоморфології та судової медицини Івано-Франківського національного медичного університету із оцінкою маси плаценти, плодово-плацентарного коефіцієнту, морфологічного дослідження гістологічних зрізів, забарвлених гематоксиліном та еозином із використанням мікроскопа Carl ZEISS Axiotar plus (Microlmaning, Німеччина).

Математичні методи дослідження включали, варіаційну і альтернативну статистику, кореляційний аналіз. Для визначення ризику розвитку ускладнень вагітності в жінок із ВХНК розраховували показники абсолютного та відносного ризиків (OR), границі $95 \%$ довірчого інтервалу (95 \% ДІ або 95 \% CI), зниження відносного ризику, їх різниці, а також показників інформативності досліджень.

За результатами ретроспективного аналізу встановлено, що варикозна хвороба нижніх кінцівок у вагітних проявляється у $32,7 \%$, із наростанням у них клінічних проявів у динаміці вагітності до III триместру до $69,1 \%$, при цьому провідними чинниками $€$ обтяжена спадковість по материнській та батьківський лінії (OR=6,9; 95\% CI:4,6-12,9), плацентарна дисфункція при попередніх вагітностях (OR=6,3; 95\% CI:2,1-29,6), ендокринно-обмінні порушення $(\mathrm{OR}=2,5 ; 95 \%$ CI:1,4-9,2), надмірна вага $(\mathrm{OR}=4,8$; 95\% CI:1,7-26,7), пухлини органів малого тазу (OR=8,5; 95\% CI:2,1-16,8), епізоди тромботичних станів (OR=10,8; 95\% CI:1,6-29,0), народження дітей малих до терміну гестації, в анамнезі $(\mathrm{OR}=13,1 ; 95 \%$ $\mathrm{CI}: 2,1-28,6)$.

Із обстежених вагітних клінічні прояви ВХНК за CEAР обмежувалися C1 та С2, телеангіектазії було виявлено в 6,7\%. Основними скаргами пацієнток були: відчуття тяжкості в нижніх кінцівках (30\%), непостійний набряк нижніх кінцівок і поєднання симптоматики - у 50 \% досліджень.

У пацієнток першої групи, домінували явища загрози мимовільного переривання вагітності (40,0\% проти 6,7 \% у контролі; $\mathrm{p}<0,05)$; порушення мікробіоценозу статевих шляхів - у 4,0 разу; ранній гестоз 
- у 3,5 разу $(23,3 \%$ проти $6,7 \%$; $<00,05)$ та анемія - у 2,5 разу. Після 20-22 тижнів вагітності отримані нами результати продемонстрували значиму частку гестаційних ускладнень, пов'язаних із ПД, зокрема: ЗРП - у 23,3 \% спостережень, невиношування - у 4,5 разу та прееклампсія - у 4,7 разу частіше $(\mathrm{p}<0,05)$, причому із появою клінічних ознак вже у терміні 24 26 тижнів гестації та набряковим синдромом (у $57,9 \%$ спостережень), що обумовило доцільність оцінки функціонального стану ФПК у такому ж методологічному аспекті (контрольна та перша група).

Симптоми ВХНК у пацієнток основної групи виникли до даної вагітності у 51 жінки (39,2 \%), у першому триместрі - у 25 осіб (19,2\%), у другому триместрі - у 19 (14,6\%), а у третьому триместрі - у 35 вагітних $(26,9 \%)$.

Аналізуючи структуру екстрагенітальної патології, слід виділити достовірно високу частку ендокринної патології $(26,1 \%)$, оперативних втручань на органах малого тазу (23,8 \%), надмірну вагу та ожиріння - у половині випадків (49,2 \%), серцевосудинні захворювання, у тому числі вегето-судинну дистонію (34,6 \%) та анемію (49,2 \%), що в 3,9 разу переважала дані у групі порівняння, а також епізоди тромботичних станів в анамнезі в основній групі - у $10,8 \%$ випадків.

Важливими для виникнення та розвитку ПД є репродуктивний анамнез. Встановлено, що тривале непліддя $(37,7 \%)$, звикле невиношування і синдром втрати плода (12,3 \%) складали комбінацію переважаючих у 1,5-1,8 разу факторів в основній групі, меншою у 2,5 разу є частка першовагітних, у 1,7 разу вищим є показник відсутності вагітностей, двоє та більше пологів в анамнезі відзначено в 2,0 разу частіше, вагомою була частка ПД при попередніх вагітностях (27,7 \% при 4,4 \% - у групі порівняння, $\mathrm{p}<0,05)$. Після 20-22 тижнів вагітності отримані нами результати продемонстрували значиму частку гестаційних ускладнень, пов'язаних із ПД, зокрема: ЗРП у 23,3 \% спостережень, невиношування - у 4,5 разу та прееклампсія - у 4,7 разу частіше $(\mathrm{p}<0,05)$, причому із появою клінічних ознак вже у терміні 24-26 тижнів гестації та набряковим синдромом (у 57,9 \% спостережень).

Отримані результати дозволяють стверджувати про збереження адаптаційно-компенсаторних особливостей ФПК у термін гестації 20-22 тижні вагітності, де тільки в 20,0 \% спостережень були сонографічні ознаки функціональних порушень, зміну обсягу навколоплідних вод $(8,3 \%)$ та ЗРП - у 13,3 \% спостережень. Тоді як у терміни 34-36 тижнів гестації встановлено більш виражені зміни, на що вказує зростання частки структурних змін плаценти - у 3,2 разу, різниці в об'ємі навколоплідних вод - у 2,6 разів, а ЗРП - у 2,2 разу (до $23,3 \%$ ), за рахунок асиметричної форми $-15,0 \%$.

Оцінка особливостей гемодинаміки ФПК напередодні розродження дозволила діагностувати порушення кровоплину у маткових артеріях - у 28,3\%, плодового кровоплину - у 18,3\%, а поєднання пору- шень маткового та плодового кровоплину - у 8,3\% спостережень, підвищення судинної резистентності у спіральних артеріях - у 21,7\% випадків, причому у третині випадків діагностика за критеріями порушення матково-плацентарного кровоплину випереджувала дані УЗД та клінічні прояви ПД. Гормональна недостатність ФПК є значимим компонентом при плацентарній дисфункції на тлі судинної патології. За результатами проведених досліджень вже в терміні 20-22 тижні гестації встановлено підвищення рівня одного або кількох маркерів у 19 (31,7\%) спостережень, дисфункцію із підвищенням плацентарних маркерів ( $\beta$-ХГЛ) та зниженням фетальних показників (Е3) - у 23 випадках (38,3\%), а також хронічну гормонопродукуючу недостатність із зниженням рівня гормонів на 50,0\% - у третині спостережень $(30,0 \%)$. Тоді як із прогресуванням вагітності, структура гормональних показників дещо змінювалася: гіперфункція встановлена в 38,3\%, дисфункція у $11,7 \%$, а виснаження гормонопродукуючої функції ФПК і депресією синтезу плацентарного лактогену та дисбалансом естріолу та кортизолу (у 1,6 разу проти даних контролю, p<0,05) - у 50,0\% спостережень.

Результати дослідження параметрів системи гемостазу в обстежених пацієнток дозволили встановити відсутність чіткої залежності між вираженістю клінічних симптомів ВХНК та глибиною змін гемостазу. Оцінка динаміки показників усіх ланок системи гемостазу в пацієнток із ПД та ВХНК продемонструвала тенденцію до гіперкоагуляції вже в терміні 20-22 тижні порівняно із показниками жінок з інтактними венами, у тому числі підвищення рівня фібриногену та зниження активності АТ-III порівняно 3 нормою.

У III триместрі вагітності встановлено більш вагомі відхилення гемостазіологічних показників, зокрема: на фоні достовірного зниження кількості тромбоцитів у групі вагітних жінок із ВХНК - у 1,6 разу, зростання їх агрегаційної активності - у 1,6 разу проти даних контролю, зниження часу рекальцифікації плазми на 22,1 \%, збільшення концентрації фібриногену в 1,4 раза, прогресуюче зниження у 1,4 разу АТ-III та зростання рівня Д-димерів у 1,7 разу $(\mathrm{p}<0,05)$.

Результати досліджень та їх обговорення. Активація стадій згортання крові, венозний застій, пошкодження стінки кровоносної судини часто виникають під час вагітності, що залежить від ваги плода, рухової активності матері, іï генетичних особливостей і багато чого іншого. У вагітних баланс між активуючими і пригнічуючими факторами гемостазу стійкий. У разі гіперкоагуляції спостерігається збільшення проактивних факторів II, V, VII, IX, X [7]. Таким чином, у жінки формується дефіцит фібринолітиків і надлишок прокоагулянтів. При вагітності виникають набуті чинники тромбофілії, які призводять до порушення згортання крові. Серед них найпоширенішими є дефіцит протеїнів C i S, антитромбіну III [8]. 
Вагітність $є$ натуральною тріадою Вірхова - жінка має стан гіперкоагуляції тільки тому, що вона є вагітною [9].

Запропонований алгоритм прогностичних і лікувально-профілактичних заходів суттєво покращив показники функціонального дискомфорту, підвищив адаптаційні можливості фетоплацентарного комплексу, що дозволило знизити частку передчасних пологів у 2,2 разу; прееклампсії, плацентарної дисфункції та дистресу плода - у 2,0 разу; і тим самим попередити негативні перинатальні наслідки: затримку розвитку плода - у 1,8 разу та рівня постгіпоксичної енцефалопатії - у 2,0 разу ( $<<0,05)$.

Висновки. 1. Варикозна хвороба нижніх кінцівок у вагітних діагностується у $32,7 \%$, із наростанням у них клінічних проявів у динаміці вагітності до III триместру до 69,1\%, при цьому провідними чинниками $є$ обтяжена спадковість по материнській та батьківський лінії (OR=6,9; 95\% CI:4,6-12,9), плацентарна дисфункція при попередніх вагітностях ( $\mathrm{OR}=6,3 ; 95 \%$ CI:2,1-29,6), ендокринно-обмінні порушення (OR=2,5; 95\% CI:1,4-9,2), надмірна вага тіла (OR=4,8; 95\% CI:1,7-26,7), пухлини органів малого тазу (OR=8,5; 95\% CI:2,1-16,8), народження дітей, малих до терміну гестації, в анамнезі $(\mathrm{OR}=13,1 ; 95 \%$
CI:2,1-28,6), епізоди тромботичних станів $(\mathrm{OR}=10,8$; 95\% CI:1,6-29,0).

2. Вагітність супроводжується станом гіперкоагуляції.

3. При варикозних проявах С1-C2 необхідно рекомендувати вагітним:

носіння еластичного трикотажу на весь гестаційний період і не менше 3-х тижнів у післяпологовому періоді;

суміш біофловоноїдів, по 1 таблетці 2 рази на добу впродовж місяця в наступні терміни 12-16, 28-32 та 34-36 тижні вагітності;

L-аргінін аспартат у сиропі по 1 мірній ложці 3 рази на добу - у терміни 12-16 та 28-32 тижні вагітності тривалістю місяць;

інгібітор агрегації тромбоцитів 100 мкг 1 раз на добу з 12 до 36 тижнів вагітності;

вагітним, які мають за шкалою Caprini та шкалою Schoenbeck помірний (3-4 бали) або високий ризик (>5 балів) появи венозного тромбоемболізму, а також при зниженні активності антитромбіну III та зростанні рівня Д-димерів, застосовувати низькомолекулярний гепарин у дозі 0,4-0,6 (підшкірно) із врахуванням індексу маси тіла - 3 моменту встановлення високого ступеня ризику - до розродження та 6-8 тижнів після пологів.

Інформація про конфлікт інтересів. Автори заявляють про відсутність конфлікту інтересів при виконанні наукового дослідження та підготовці даної статті.

Інформація про фінансування. Автори гарантують, що вони не отримували жодних винагород у будь-якій формі, здатних вплинути на результати роботи.

Особистий внесок кожного автора у виконання роботи:

Пиптюк О.В. - розробка концепції і дизайну дослідження, аналіз отриманих даних, редагування, статистична обробка даних.

Моцюк Ю.Б. - збір матеріалу дослідження, аналіз отриманих даних, підготовка тексту статті.

\section{Список використаної літератури}

1. Медведь В. І., Кирильчук М. Є., Ісламова О. В., Автомеєнко А. І., Савка Т. Р. Профілактика венозного тромбоемболізму у вагітних груп ризику: клініко-інструментальне дослідження. Здоровье женщины. 2017;№3 (119):73-8.

2. Cohen A.T., Agnelli G., Anderson F.A. et al. Venous thromboembolism (VTE) in Europe. Thromb Haemost. 2007;98(4):756-64.

3. Борківець О. М. Особливості перебігу варикозної хвороби вен у вагітних. Міждисциплінарні проблеми. 2018;6.

4. В. О. Потапов В. Г. Сосюра Г. О. Жернова В. Г. Шапран Лікування і реабілітація вагітних та профілактика зумовлена нею ускладнень. Здоровье женщины. 2014;10 (96): 71-5.

5. Elalamy I. Venous thrombosis in pregnant women: genetic and epigenetic risk factors. Obstetrics, Gynecology and Reproduction. 2019;13(3):245-54.

6. Scheres J.J., Lijfering W.M., Cannegieter S.C. Current and future burden of venous thrombosis: Not simply predictable. Res Pract Thromb Haemost. 2018;2(2):199-208.

7. Di Nisio M., van Es N., Büller H.R. Deep vein thrombosis and pulmonary embolism. Lancet. 2016388 (10063): 3060-73.

8. Takagi Y., Murata M., Kozuka T. et al. Missense mutations in the gene encoding prothrombin corresponding to Arg596 cause antithrombin resistance and thrombomodulin resistance. Thromb Haemost. 2016;116(6):1022-31.

9. Conti E., Zezza L., Ralli E. et al. Pulmonary embolism in pregnancy. J Thromb Thrombolysis. $2014 ; 37$ (3): 251-70.

Стаття надійшла до редакції: 20.02.2020 р. 